Navigation Physics 2(2)(2020)
Navigation Physics
Journal of Physics Education

\title{
Pengembangan Model Miniatur Kereta Magnetic Levitation Sebagai Media Pembelajaran Fisika Pada Materi Gaya Magnetik
}

\author{
Andry Fitrian, Iman Noor \\ Universitas Indraprasta PGRI \\ E-mail: andryakira@gmail.com
}

\begin{tabular}{|c|c|}
\hline Info Artikel & Abstract \\
\hline $\begin{array}{l}\text { Sejarah Artikel: } \\
\text { Diterima November } 2020 \\
\text { Disetujui November } 2020 \\
\text { Dipublikasikan Desember } 2020\end{array}$ & $\begin{array}{l}\text { The purpose of this research is to produce a development product in the } \\
\text { form of a Magnetic Levitation Train miniature model that can be used by } \\
\text { teachers and students in the physics learning process on magnetic force } \\
\text { material in class XII. This study uses research and development methods. }\end{array}$ \\
\hline $\begin{array}{l}\text { Keywords: } \\
\text { Alat peraga, model miniature, Kereta } \\
\text { Magnetic Levitation }\end{array}$ & $\begin{array}{l}\text { reviewing curriculum standard notes. The second stage is the design of the } \\
\text { tool, making a miniature model of the Magnetic Levitation Train and the } \\
\text { use of a miniature model of the Magnetic Levitation Train in the learning } \\
\text { process. The third stage is the implementation stage, the miniature model } \\
\text { of the Magnetic Levitation Train was tested on high school student of class } \\
\text { XII to measure students against the miniature model of the Magnetic } \\
\text { Levitation Train as a tool to help students understand the concept of } \\
\text { magnetic force. The instrument uses a Likert Scale. With three stages, the } \\
\text { researcher succeeded in making a miniature model of the Magnetic } \\
\text { Levitation Train that was worthy of being one of the learning media on } \\
\text { magnetic force material by obtaining information that the validation results } \\
\text { by experts, material personnel and students obtained a very good level of } \\
\text { measurement which was in the interpretation range of scores } 80-100 \% \text { so it } \\
\text { is necessary to develop a miniature model of the Magnetic Levitation Train } \\
\text { to be even better in further research. }\end{array}$ \\
\hline
\end{tabular}

How to Cite: Fitrian, A., \& Noor, I. (2020). Pengembangan Model Miniatur Kereta Magnetic Levitation Sebagai Media Pembelajaran Fisika Pada Materi Gaya Magnetik. Navigation Physics, 2 (2): 90-97.

\section{PENDAHULUAN}

Pelaksanaan pembelajaran adalah suatu bentuk penyelenggaraan kegiatan pembelajaran yang memadukan secara sistematis dan berkesinambungan. Salah satu faktor terpenting dari belajar adalah keterlibatan peserta didik secara aktif dalam proses pembelajaran. Menurut Rusman (2010) Siswa harus terlibat secara aktif dalam mengamati, mengoperasikan alat, atau berlatih menggunakan objek kongkrit sebagai bagian dari pelajaran. Dalam proses pembelajaran, guru hendaknya dapat melakukan pengajaran menggunakan media. Hal ini penting karena keadaan peserta didik di dalam kelas sangat heterogen. Media tersebut dapat berupa model, objek, alat peraga, miniatur dan media lainnya yang dapat membantu guru memaksimalkan pembelajaran supaya peserta didik dapat lebih mudah memahami pelajaran tersebut.

Namun kenyataannya penggunaan media untuk pembelajaran fisika SMA masih kurang memadai. Keterbatasan media tersebut membuat peserta didik mengalami kesulitan untuk mengetahui contoh-contoh fenomena fisika. Menurut Pauliza (2015), pemberlakuan pada setiap Kurikulum menuntut peserta didik lebih memiliki kompetensi khusus dalam semua pelajaran setelah proses pembelajaran. Terlebih dalam pendidikan sains yang mengarahkan peserta didik untuk "mencari tahu" dan "berbuat" sehingga dapat membantu peserta didik memperoleh pemahaman yang lebih mendalam tentang alam sekitar. Sehingga proses pembelajaran fisika lebih menekankan pada pemberian pengalaman langsung 
untuk mengembangkan kompetensi agar peserta didik menjelajahi dan memahami alam sekitar secara ilmiah.

Salah satu fenomena dalam fisika adalah mengenai medan magnetik. Dalam konsep ini menerangkan juga mengenai induksi magnetik yaitu peristiwa dihasilkannya arus listrik yang mengalir dalam konduktor dan gaya magnetik yaitu gaya yang bekerja pada sebuah penghantar berarus listrik dalam medan magnet. Dan terdapat aplikasi gaya magnetik bagi kehidupan sehari-hari salah satunya yaitu Kereta Maglev, namun bila kita melihat beberapa buku, modul, maupun alat peraga fisika untuk SMA hanya sebatas gambar kereta dan prinsip kerja yang minim dijelaskan. Terlebih lagi kit yang terdapat di sekolah-sekolah SMA tidak ada yang menjelaskan prinsip kerja dari Kereta Maglev tersebut. Oleh karena itu peneliti tertarik mengembangkan aplikasi Maglev tersebut dalam wujud media minatur.

Berdasarkan jurnal international Jaiaraman dan Madhu (2015) berjudul "A research review on magnetic levitation trains" dengan kesimpulan bahwa Kereta Maglev memiliki banyak keunggulan seperti kecepatannya dapat melebihi $300 \mathrm{~km} / \mathrm{jam}$, tidak mengkonsumsi bahan bakar, biaya perawatan lebih murah dan lebih sedikit suar bisingnya. Lalu pada jurnal internasional dari Soares, dan Ferreira, etc. (2016), dengan judul "Magnetic levitation-based electromagnetic energy harvesting: a semi-analytical non-linear model for energy transduction" dengan kesimpulan bahwa model untuk transduksi energi dapat dioptimalisasi sebelum fabrikasi dan desain secara permanen. Sehingga dari jurnal tersebut dapat penulis simpulkan bahwa Kereta Maglev belum banyak dikembangkan khusunya pada bidang Pendidikan terutama di Indonesia. Kemudian dalam analisis kebutuhan terhadap guru fisika dapat disimpulkan $100 \%$ (diambil dari 5 guru fisika SMA) membutuhkan media miniatur Kereta Maglev sebagai salah satu media pembelajaran fisika pada materi gaya magnetik

Media miniatur merupakan salah satu alternatif media yang dapat dijangkau bila model, alat atau pun bahan sulit untuk di bawa pada saat pembelajaran. Terlebih lagi pada pembelajaran fisika yang terus menerus mengalami kemajuan. Dengan merunut pada standar kompetensinya yaitu menerapkan konsep kelistrikan dan kemagnetan dalam berbagai penyelesaian masalah dan produk teknologi, lalu kompetensi dasarnya yaitu menerapkan induksi magnetik dan gaya magnetik pada beberapa produk teknologi, kemudian merunut pada penelitian-penelitian tentang Kereta Maglev sebelumnya, dengan adanya miniatur Kereta Maglev ini diharapkan aplikasi untuk pembelajaran gaya magnetik dapat dilihat secara nyata dalam pembelajaran fisika dan dapat dikembangkan terutama di Indonesia.

\section{METODE PENELITIAN}

Metode penelitian yang digunakan adalah pengembangan (Research and Development). Penelitian pengembangan adalah suatu proses atau langkah-langkah untuk mengembangkan suatu produk baru atau menyempurnakan produk yang telah ada, yang dapat di pertanggung jawabkan. Penelitian pengembangan ialah suatu proses yang digunakan untuk mengembangkan dan memvalidasi paket materi pendidikan, seperti materi pembelajaran, buku teks, metode pembelajaran, desain instruksional, yang digunakan dalam suatu penelitian pengembangan. Produk yang dihasilkan yaitu model miniatur Kereta Magnetic Levitation.

Langkah-langkah proses penelitian pengembangan dari Borg and Gall (2014) adalah:

1) Penelitian dan pengumpulan data (research and information collecting)

2) Perencanaan (Planning)

3) Pengembangan draft produk (develop preliminary form of product)

4) Uji coba lapangan awal (preliminary field testing)

5) Merevisi hasil uji coba (main product revision)

6) Uji coba lapangan (main field testing)

7) Penyempurnaan produk hasil uji lapangan (operational product revision)

8) Uji pelaksanaan lapangan (operational field testing)

9) Penyempurnaan produk akhir (final product revision), dan

10) Diseminasi dan implementasi (disseminasion and implementation)

Desain penelitian pengembangan disusun berdasarkan langkah-langkah penelitian pengembangan dalam Sukmadinata (2011). Desain penelitian pengembangan yang akan dilakukan adalah sebagai berikut: 


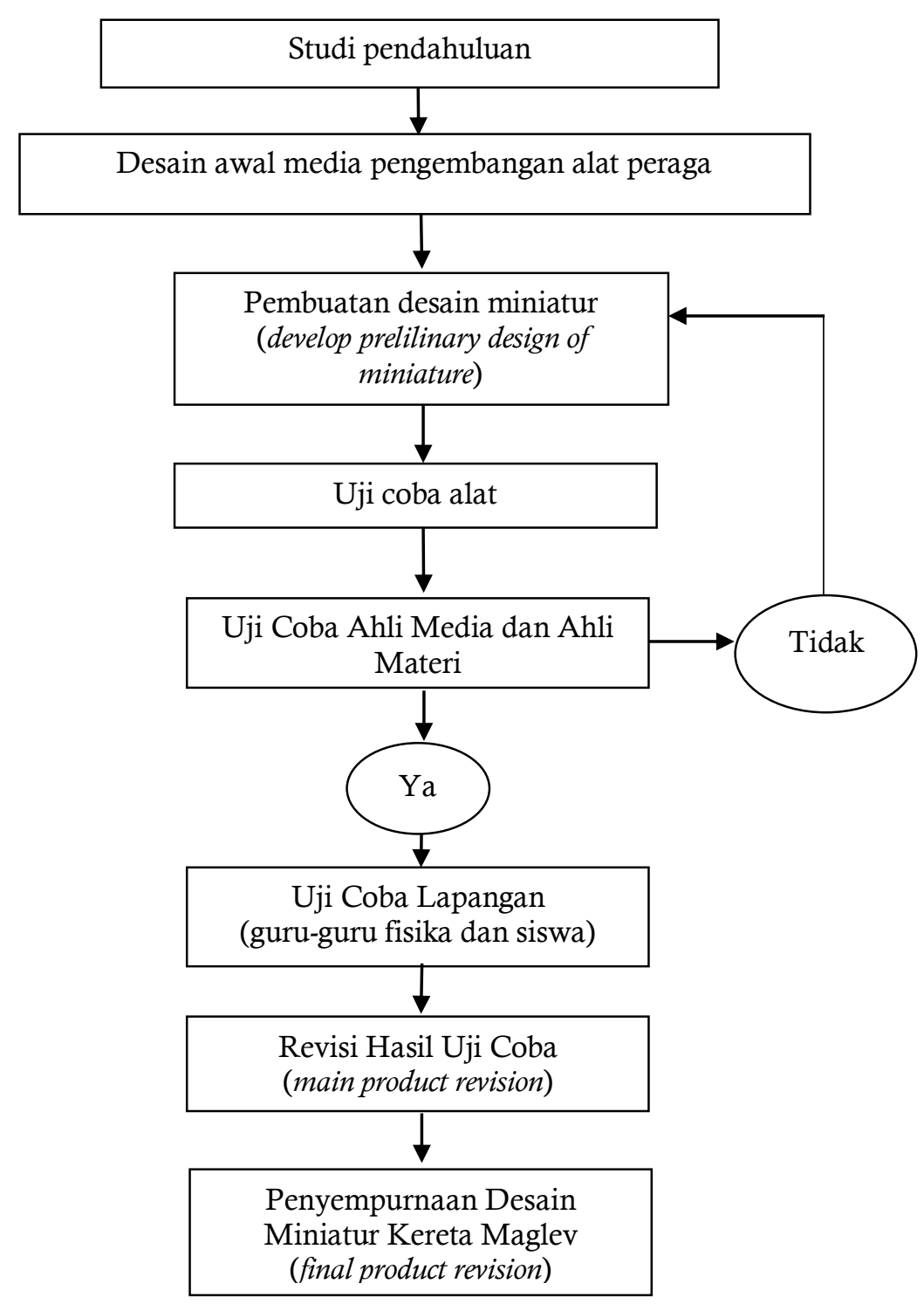

Gambar 1. Desain Penelitian Pengembangan

\section{HASIL DAN PEMBAHASAN}

Model miniatur Kereta Magnetic Levitation dikembangkan melalui studi literatur dengan menggunakan beberapa buku teks, jurnal dan pencarian melalui internet. Penelitian pengembangan model miniatur Kereta Magnetic Levitation dilakukan dalam beberapa tahap, yaitu:

1. Studi pendahuluan

Studi pendahuluan dilakukan dengan cara menelaah kurikulum. Hal-hal yang dilakukan dalam telaah ini yaitu: (1) menentukan standar kompetensi dan kompetensi dasar; (2) mempelajari tuntutan dari standar isi; (3) membuat indikator yang sesuai standar kompetensi dan kompetensi dasar. 


\section{Tahap pembuatan}

Pengembangan desain awal dimulai dari menentukan material yang akan dibuat dan membuat gambar atau skema model miniatur Kereta Magnetic Levitation.

Proses pembuatan miniatur dibagi menjadi tiga bagian, yaitu :

a. Bagian Kereta Maglev

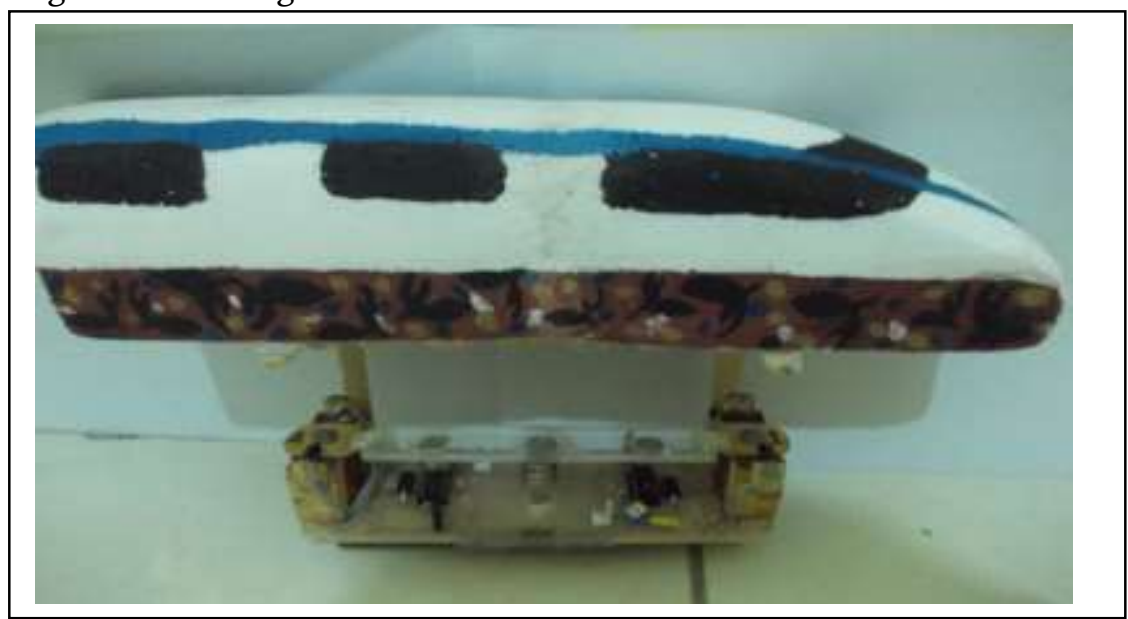

Gambar 2. Model miniatur Kereta Magnetic Levitation tampak samping

Kereta Magnetic Levitation terbuat dari sterefoam, bagian bawah kereta menggunakan magnet permanen yang berfungsi sebagai pengatur maju mundurnya kereta dengan diameter $1,1 \mathrm{~cm}$ tebal $0,2 \mathrm{~cm}$. Bagian pelayangan menggunakan dua buah kumparan/coil berdiameter $0,24 \mathrm{~mm} / 2,46$ ohm dengan intinya menggunakan paku berdiameter $10 \mathrm{~mm}$ lalu disambung menggunakan acrylic sepanjang $11 \mathrm{~cm}$ yang ditengahnya terdapat magnet permanen sebagai penstabil/kalibrasi kereta. Terdapat pula di bagian atas kumparan berupa sensor pembaca dari infra red dan photo diode. Bagian pelayangan juga memiliki rangkaian pelayang. Pada bagian pelayangan dan kereta disambung menggunakan stik es. Bagian paling bawah menggunakan besi panjang sebagai pemberat dan penstabil kereta.

\section{b. Bagian rel Kereta Maglev}

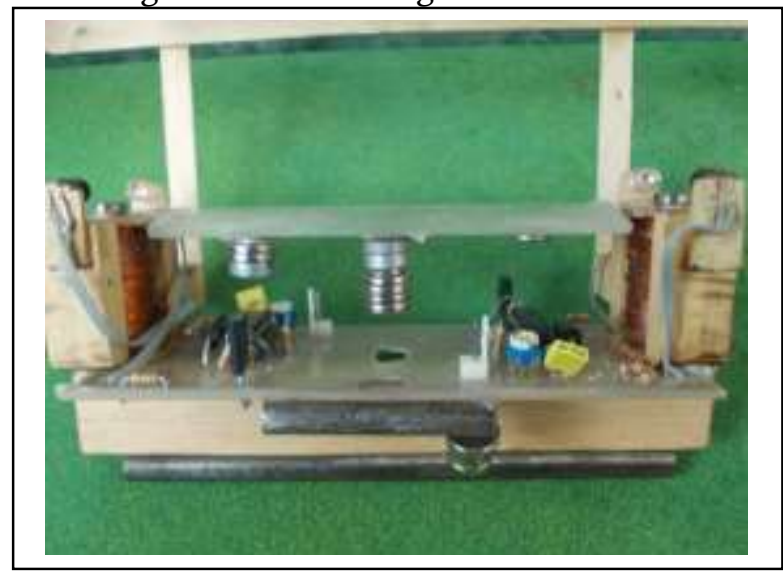

Gambar 3. Rangkaian pelayangan

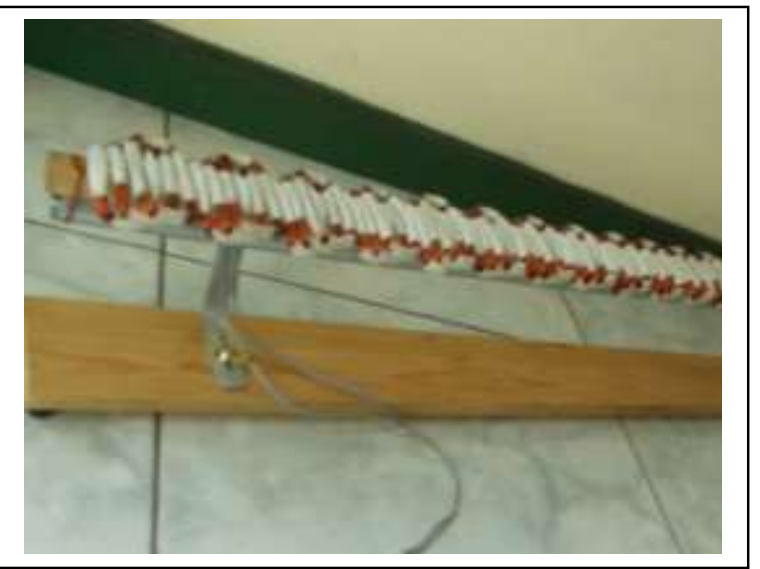

Gambar 4. Rel Kereta Magnetic Levitation

Bagian bawah sebagai alas menggunakan kayu berukuran $100 \times 7,5 \mathrm{~cm}$. Untuk pelayangan Kereta Maglev digunakan bahan ferromagnetik yaitu besi yang panjangnya $100 \mathrm{~cm}$ dengan diameter luarnya $2,04 \mathrm{~cm}$ dan diameter dalamnya $1,8 \mathrm{~cm}$. Dan bagian atasnya berupa kumparan yang diputar sebanyak 80 kali dengan lebar $5 \mathrm{~cm}$ dan dirangkai sepanjang $100 \mathrm{~cm}$ (kumparan ini dibuat tiga kali). Soket pada ujung kumparan sebagai sambungan untuk dialiri arus. 
c. Bagian set pengontrol dan catu daya

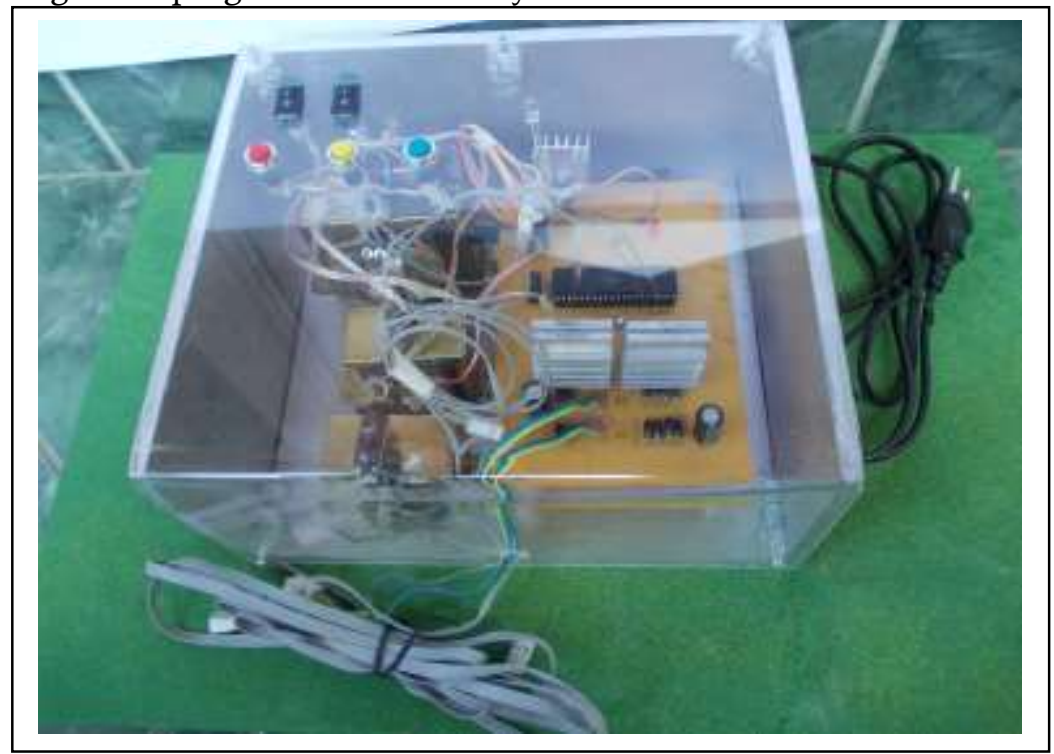

Gambar 5. Set pengontrol dan Catu Daya tampak atas

Desain pelindung (casing) bagian bawah, kiri, kanan dan belakang menggunakan kayu. Bagian bawah berukuran 22x19,5 cm, bagian kiri dan kanan berukuran 19,5x10 $\mathrm{cm}$, bagian belakang berukuran $22 \times 20 \mathrm{~cm}$. Catu Daya menggunakan sumber tegangan 220 Volt di buat menjadi arus DC. Untuk arus pelayangan memakai masing-masing 24 Volt untuk satu kumparan pelayangan dan untuk pengontrol memakai 18 Volt. Terdapat IC mikrokontroler yang digunakan yaitu IC AVR AT-Mega 16A juga 1 tombol untuk memajukan kereta, 1 tombol memundurkan kereta, 1 tombol berhenti, dan 1 tombol on/off arus untuk pengontrol dan 1 tombol on/off arus untuk gerakan kereta.

3. Uji coba awal oleh tenaga ahli

Model miniatur Kereta Magnetic Levitation yang telah dibuat kemudian diuji coba oleh tenaga ahli. Uji coba dilakukan oleh 7 orang yang terdiri dari 2 uji ahli materi (dosen), 2 uji ahli media (dosen) dan 3 orang guru Fisika. Setiap ahli diberikan lembar kuesioner yang berisi pernyataan yang berkaitan dengan kesesuaian media dengan aspek yang dituju. 


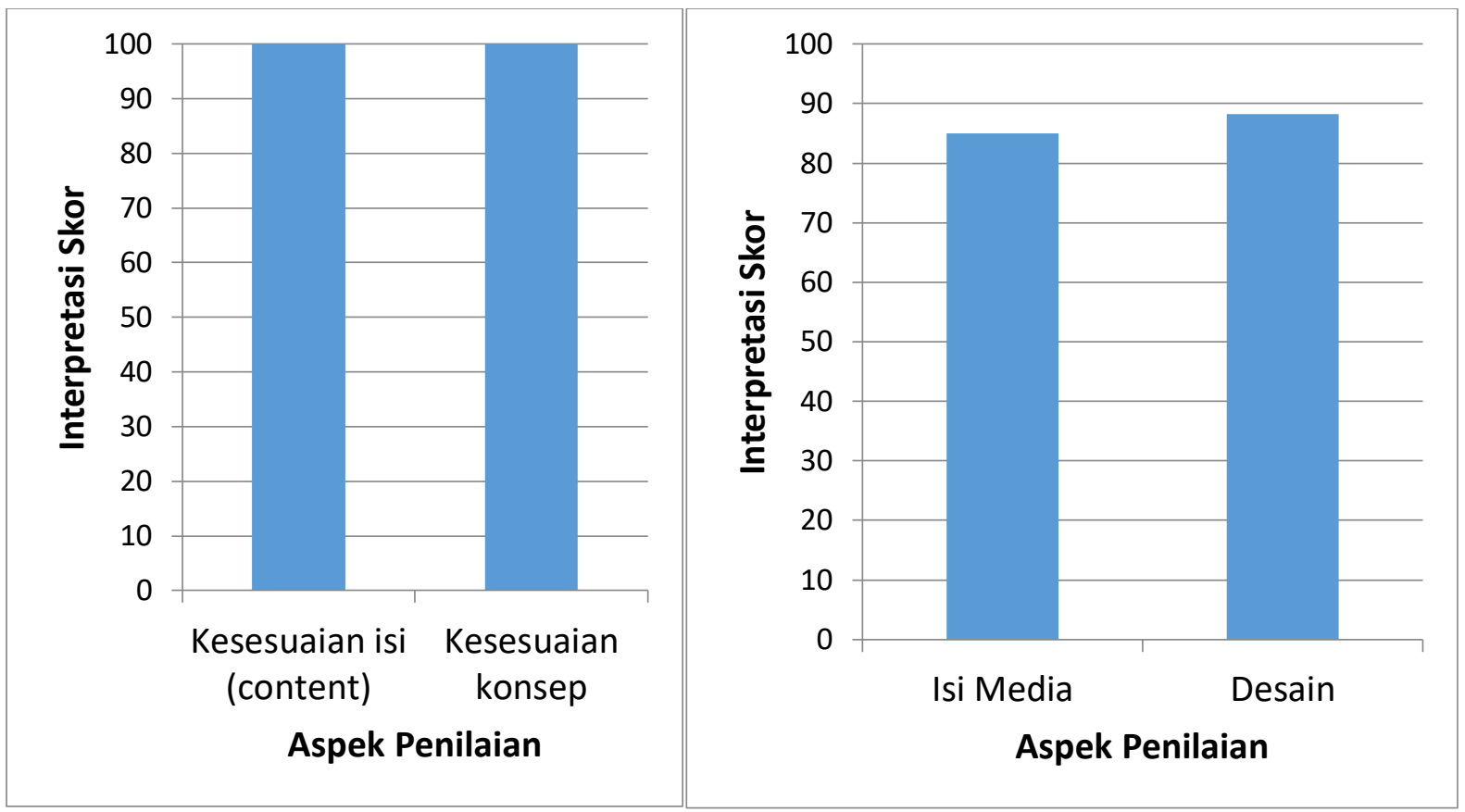

Gambar 5. Diagram validasi tenaga ahli (dosen ahli materi dan ahli media)

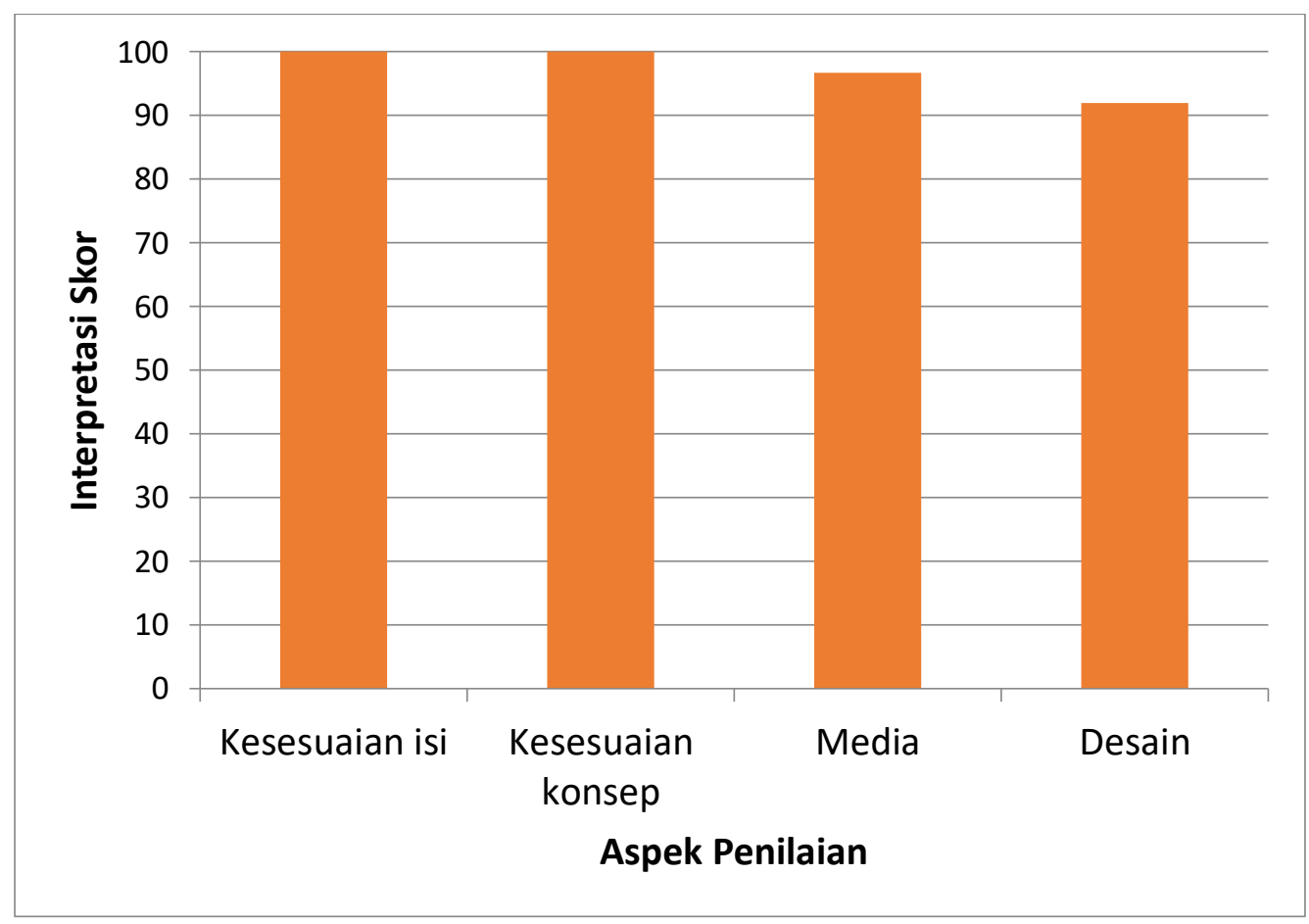

Gambar 6. Diagram validasi tenaga ahli (guru)

4. Uji coba media terhadap siswa

Uji coba pelaksanaan lapangan terhadap siswa dilakukan di SMA Widya Nusantara Bekasi dengan populasi target adalah siswa SMA kelas XII. Uji coba dilakukan dengan mendemonstrasikan model miniatur Kereta Magnetic Levitation dalam proses pembelajaran. Kemudian siswa mengisi lembar kuesioner yang diberikan terdiri dari 9 pertanyaan tentang minat belajar siswa. 


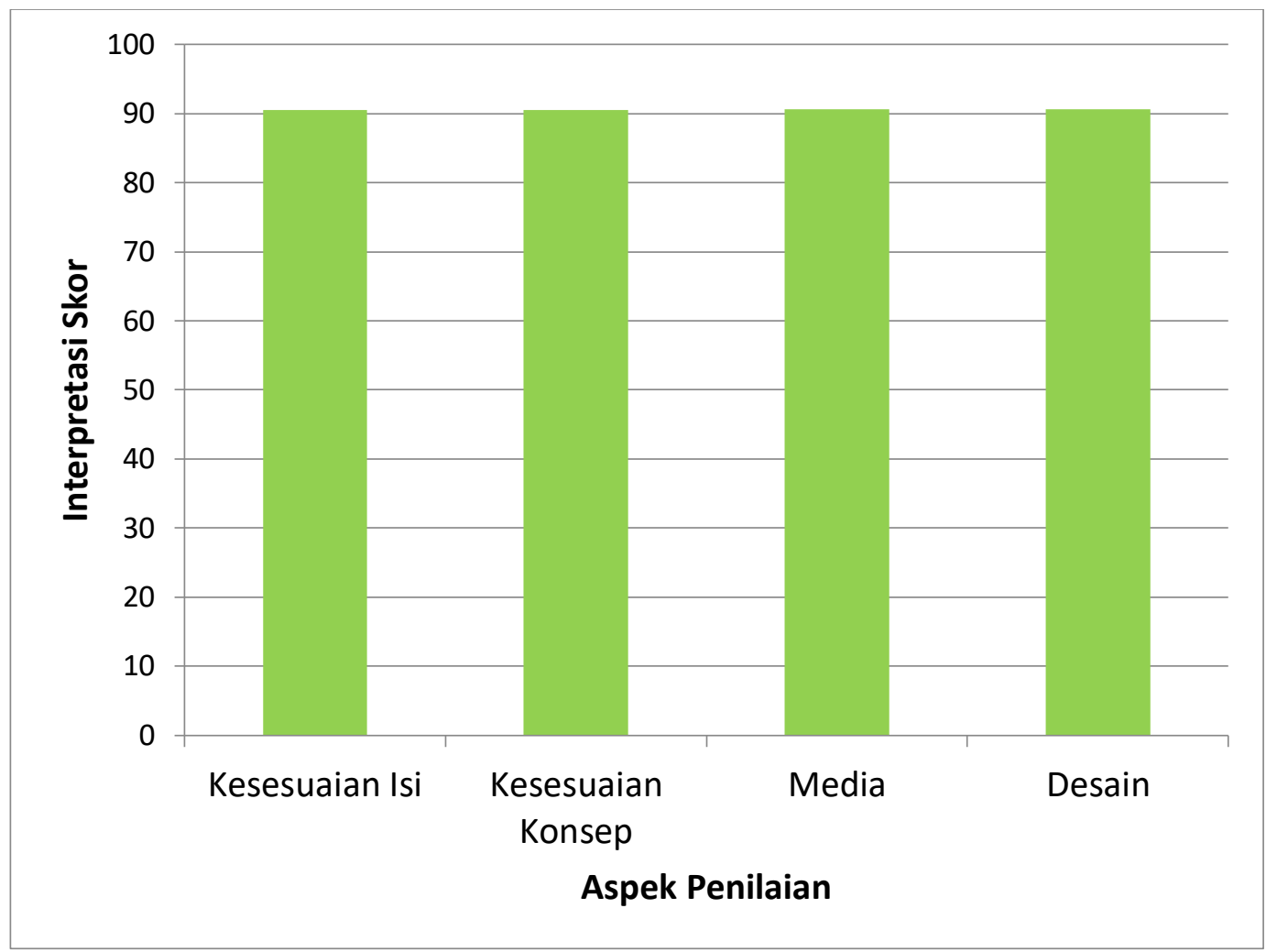

Gambar 7. Diagram validasi siswa

5. Penyempurnaan desain miniatur

Penyempurnaan desain miniatur didasarkan pada masukan, saran dan pendapat dari hasil uji coba yang telah dilakukan sebelumnya. Dari tahap penelitian pengembangan yang telah dilakukan akan menghasilkan sebuah produk model miniatur Kereta Magnetic Levitation dengan segala perlengkapannya.

Berdasarkan keempat aspek penilaian yaitu kesesuaian isi (content), kesesuaian konsep, media, dan desain rentang interpretasi skor rata-rata yang di dapat berada pada rentang $80-100 \%$ (sangat baik). Pada uji validasi yang dilakukan bahwa model miniatur Kereta Magnetic Levitation berkaitan dengan kesesuaian dari standar isi dan penggunaan media miniatur sebagai alat bantu pembelajaran di sekolah untuk membantu siswa mencapai kompetensi dasar yang harus dicapai.

Media miniatur yang telah dihasilkan harus sesuai dengan konsep fisika sehingga tidak menimbulkan miskonsepsi. Di samping itu, media miniatur harus menarik, praktis, serta mudah dalam penggunaannya sehingga dapat menarik perhatian siswa saat digunakan dalam proses pembelajaran. Model miniatur Kereta Magnetic Levitation diharapkan dapat memberikan pengalaman belajar secara langsung dan lebih konkrit kepada siswa.

Kemudian berdasarkan hasil uji coba terhadap siswa, didapatkan interpretasi skor kesesuaian isi (content), kesesuaian konsep, media dan desain berada pada rentang 80-100\%. Dari hasil kuesioner, siswa menyatakan bahwa lebih mudah memahami aplikasi dari konsep induksi magnetik dan gaya magnetik menggunakan model miniatur Kereta Magnetic Levitation. Berdasarkan penelitian relevan berjudul "Rancang bangun sistem kereta maglev sebagai simulasi kontrol gerak levitasi pada kereta maglev" oleh Firdaus dan Muslim (2018) hanya membuat prototipe untuk mensimulasikan proses levitasi pada kereta maglev dengan solenoida sebagai aktuarot sehingga membutuhkan miniatur yang lebih baik untuk mengukur proses levitasinya. Demikian juga penelitian oleh Liu dan Yuan (2013) berjudul "Diamagnetic levitation for nonlinear vibration energy harvesting: theoretical modeling and analysis" dengan kesimpulan untuk menghasilkan pembahasan bahan diamagnetik pada mekanisme pelayangan namun hanya batasan analisis teori. Juga penelitian Zhang dan Tao (2020) dengan judul "Model predictive control of a magnetic levitation system using two-level state feedback" dengan menghasilkan sistem pelayangan magnetik yang kurang stabil dapat lebih distabilkan dengan sistem two-level state feedback sehingga lebih presisi dan dapat stabil. Berdasarkan jurnal-jurnal penelitian tersebut dapat diambil kesimpulan sebagai teori tolak ukur sehingga model miniatur Kereta Magnetic Levitation menjadi aplikasi dari penelitian tersebut. 


\section{PENUTUP}

Berdasarkan hasil penelitian dan pembahasan, dapat ditarik kesimpulan bahwa model miniatur Kereta Magnetic Levitation memenuhi syarat-syarat yang relevan dengan standar kompetensi dan kompetensi dasar pada pembelajaran fisika. Model miniatur Kereta Magnetic Levitation juga memenuhi syarat sebagai media pembelajaran yang tepat untuk materi aplikasi dari induksi magnetik dan gaya magnetik sehingga memudahkan siswa untuk mengamati proses dari konsep induksi magnetik dan gaya magnetik.

Setelah dilakukan uji validasi. Diperoleh saran, antara lain perlu adanya track untuk memuluskan gerakan kereta dan dilengkapi alat ukur arus juga ditambahkan penjelasan fisis mekanisme Magnetic Levitation dan bergeraknya Kereta Maglev. Oleh karena itu, perlu dilakukan pengembangan lebih lanjut untuk meningkatkan manfaat model miniatur Kereta Magnetic Levitation yang telah dihasilkan. Sehingga model miniatur Kereta Maglev yang telah dibuat peneliti ini layak sebagai media pembelajaran fisika pada materi gaya magnetik dan lebih utamanya lagi dikarenakan belum ada kereta maglev di Indonesia.

\section{UCAPAN TERIMA KASIH}

Ucapan terima kasih yang sebesar-besarnya kepada ketua, sekretaris dan rekan-rekan sejawat program studi Pendidikan Fisika Universitas Indraprasta PGRI.

\section{DAFTAR PUSTAKA}

Borg W.R., Gall J.P and Gall M.D. (2014). Appliying Educational Research, 7th edition. London: Pearson Education.

Firdaus, Reza Kamal \& Muslim, M. Aziz. (2018). Rancang Bangun Sistem Kereta Maglev Sebagai Simulasi Kontrol Gerak Levitasi Pada Kereta Maglev. Jurnal Mahasiswa TEUB Vol. 6 (3), 1-6.

Jaiaraman, Sujay \& S., Madhu. (2015). A research review on magnetic levitation trains. International Journal of Applied Engineering Research. Vol.. 10 (33), 1-7.

Liu, L \& Yuan F.G. (2013). Diamagnetic levitation for nonlinear vibration energy harvesting: theoretical modeling and analysis. J. Sound Vib. 332(2), 455-464

Pauliza, Osa. (2015). Strategi Pembelajaran Fisika. Universitas Malang.

Rusman. (2010). Model-model Pembelajaran. Jakarta: PT RajaGrafindo Persada.

Soares, Marcos P., Ferreira, Jorge. A.F., Simoes, Jose A.O., Pascoal, Ricardo., Torrao, Joao., Xue, Xiaozheng \& Furlani, Edward P. (2016). Magnetic levitation-based electromagnetic energy harvesting: a semi-analytical non-linear model for energy transduction. 6: 18579.

Sukmadinata, Nana Syaodih. (2011). Landasan Psikologi Proses Pendidikan. Bandung: Remaja Rosdakarya.

Zhang, Zhenlin., Zhou, Younghua \& Tao, Xin. (2020). Model predictive control of a magnetic levitation system using two-level state feedback. Measurement and control, Vol 53 (5-6) 